\title{
Current Treatment Strategies in Brain Metastases
}

\author{
G. Schackert S. B. Sobottka A. Steinmetz M. Kirsch
}

\section{Key Words}

Brain metastases - Surgery · Radiosurgery - Radiotherapy · Chemotherapy

\section{Summary}

Brain metastases are treated with surgery, radiotherapy, radiosurgery, and chemotherapy. In this review, recently published studies concerning different treatment strategies are presented with respect to solitary lesions, multiple metastases, and recurrent tumor growth. Selection criteria for the appropriate therapy are: control of the primary tumor, extent of extracerebral metastases, time interval between diagnosis of the primary tumor and the development of cerebral lesions, number of cerebral metastases, Karnofsky performance scale score, and age. Treatment approaches were evaluated with respect to median survival time and quality of life.

A singular brain metastasis can be treated with surgery or with radiosurgery. Especially when the primary tumor is under control, there are few extracerebral lesions which are stable, the Karnofsky performance scale score is above 70 , the lesion is larger than $3 \mathrm{~cm}$ in diameter and surgically accessible surgery is the treatment of choice. Postoperative adjuvant radiotherapy may delay relapse. Median survival time ranges between 10 to 18 months. Radiosurgery can be applied in lesions smaller than $3 \mathrm{~cm}$ in diameter and is the treatment of choice in lesions which are surgically not accessible. Multiple metastases are treated either by conventional radiotherapy, radiosurgery or surgery. Commonly, no more than 3 lesions are approached by either surgery or radiosurgery. Median survival time ranges between 6 to 9 months for both treatment concepts, but without therapy only is $4-6$ weeks. According to the clinical and neurological condition of the patient, recurrent brain metastases can be treated by operation, reirradiation, or radiosurgery. The efficacy of chemotherapy depends on the chemosensitivity of the primary tumor and the ability to penetrate the blood-brain barrier. Long-term survivors with cancer disease encourage to perform active treatment strategies.

\section{Schlüsselwörter}

Hirnmetastasen · Chirurgie · Radiochirurgie · Strahlentherapie $\cdot$ Chemotherapie

\section{Zusammenfassung}

Hirnmetastasen werden durch Operation, Ganzhirnbestrahlung, Radiochirurgie und Chemotherapie behandelt. In dieser Übersichtsarbeit werden kürzlich publizierte Studien bezüglich derTherapiekonzepte für solitäre Läsionen, multiple Metastasen und Tumorrezidive vorgestellt. Auswahlkriterien für eine angemessene Behandlung sind: Kontrolle des Primärtumors, Ausmaß der extrakraniellen Metastasen, Zeitintervall zwischen Diagnose des Primärtumors und dem Auftreten der Hirntumoren, Anzahl der zerebralen Metastasen, Karnofsky-Performance-ScaleScore und Lebensalter. Behandlungskonzepte wurden nach der medianen Überlebenszeit und Lebensqualität ausgewertet. Singuläre Hirnmetastasen können operativ oder radiochirurgisch behandelt werden. Insbesondere wenn der Primärtumor unter Kontrolle ist, wenige extrazerebrale Läsionen bestehen und diese stabil sind, der Karnofsky-Performance-Scale-Score über 70 ist, die Tumoren größer als $3 \mathrm{~cm}$ im Durchmesser und chirurgisch erreichbar sind, ist die Operation die Methode der Wahl. Postoperative adjuvante Strahlentherapie kann erneute Progression verzögern. Die mediane Überlebenszeit liegt zwischen 10 und 18 Monaten. Für Läsionen, die kleiner als $3 \mathrm{~cm}$ sind und chirurgisch nicht erreicht werden können, ist die Radiochirurgie die Therapie der Wahl. Multiple Metastasen können durch konventionelle Ganzhirnbestrahlung, Radiochirurgie oder Operation behandelt werden. Im allgemeinen werden nicht mehr als 3 Herde operativ oder radiochirurgisch angegangen. Die mediane Überlebenszeit liegt bei beiden Therapieformen zwischen 6 und 9 Monaten, ohne Behandlung hingegen bei nur 4-6 Wochen. Entsprechend dem klinischen und neurologischen Zustand der Patienten können Rezidive von Hirnmetastasen durch chirurgische Entfernung, erneute Bestrahlung oder durch Radiochirurgie therapiert werden. Die Wirkung der Chemotherapie hängt von der Chemosensitivität des Primärtumors und der Durchlässigkeit der Blut-Hirn-Schranke für das Chemotherapeutikum ab. Langzeitüberleber motivieren zu aktiven Behandlungsstrategien.

\begin{tabular}{ll}
\hline KARGER & ( 2000 S. Karger GmbH, Freiburg \\
Fax +49 7614520714 & Accessible online at: \\
$\begin{array}{l}\text { E-mail Information@Karger.de } \\
\text { www.karger.com }\end{array}$ & www.karger.com/journals/onk
\end{tabular}

Prof. Dr. med. Gabriele Schackert Abteilung für Neurochirurgie Technische Universität Dresden Fetscherstraße 74, D-01307 Dresden (Germany) Tel. +49 351 458-2886/2883, Fax -4304 


\section{Introduction}

Metastases to the brain occur in approximately $20-40 \%$ of all patients with carcinoma [1,2] and comprise more than $30 \%$ of all brain tumors. Most cerebral metastases originate from primary lung tumors in $25 \%$, from breast tumors in $21 \%$, and from malignant melanoma in $10-15 \%$. Autopsy data reveal that almost $70-90 \%$ of all patients with malignant melanoma develop cerebral lesions [3]. At the time of diagnosis more than $50 \%$ of the patients present with multiple lesions. There is a rising incidence of brain metastases, since advanced treatment strategies for extracerebral cancer prolong patient's survival and allow for development of brain metastases [4].

The goal in treating brain metastases is to eliminate the lifethreatening brain lesion that raises intracranial pressure and causes neurological deficits. Because brain metastases usually occur in the final stage of cancer, patients face reduced life expectancy. The median survival time without treatment ranges between 1 and 3 months $[5,6]$. One of the major aims in treating these patients is to maintain or to improve their quality of life. Many treatment modalities have been applied during recent years. Prognostic factors have been evaluated that are associated with prolonged survival of patients. Here we review current treatment strategies according to recently published studies.

\section{Diagnosis}

Initial neurological symptoms of brain metastases include headaches, seizures or neurological deficits, e.g. hemiparesis, aphasia or hemianopsia. Mass effects lead to symptomatic elevated intracranial pressure with headaches, dizziness, vomiting, drowsiness and finally loss of consciousness. The diagnosis is usually made by cerebral computed tomography (CT) or magnetic resonance imaging (MRI). The typical diagnostic image on contrast-enhanced CT and T1-weighted MRI resembles a garland-like ring with central necrosis [7]. Very small lesions of less than $1 \mathrm{~cm}$ in diameter can be detected by T2weighted MRI, demonstrating an edematous alteration of the parenchyma. MRI has to be applied on a routine basis in preoperative diagnosis of cerebral metastasis $[8,9]$. Additional lesions may be detected that have not been visualized by CT scan. The sensitivity of MRI can be enhanced by high-dose application of contrast media [10,11], by the interval of time between i.v. injection of contrast media and imaging, and by the field strength of the scanner. The diagnosis of multiple cerebral metastases is crucial for further treatment decisions. Brain metastases of certain origin, e.g. from melanoma or hepatocellular carcinoma, tend to cause hemorrhage. The sudden onset of symptoms leads to differential diagnostic considerations, including spontaneous intracerebral hemorrhage without association with neoplastic disease. Murakami et al. [12] presented a series of 16 cases of hepatocellular carcinomas with brain metastases. Eight of these patients suffered from apoplexy-like symptoms; in 14 patients a hemorrhage had occurred. The authors point out the value of contrast-enhanced CT or MRI scan to differentiate between bleeding and tumorassociated bleeding.
In a prospective study by van de Pol [13] the question was raised whether primary staging of asymptomatic small-cell lung cancer patients should routinely include an MRI scan of the brain. The results of this study indicate that most patients develop clinical symptoms leading to the diagnosis of a cerebral lesion and that the routine scan of the brain rarely detects metastases at an early state. This study addresses the important question whether tumor staging in cancer patients has to include brain examination on a routine basis at least in primaries which tend to seed in the brain. Considering the development of metastases in functionally silent areas of the brain or as very small asymptomatic lesions, they might be undetected, although their detection will greatly influence treatment strategies (see below).

\section{Microneurosurgical Therapy of a Single Brain Metastasis}

In recent years, several studies have provided evidence that surgical excision of a brain metastasis optimizes quality of life and prolongs survival time. In a randomized prospective study by Patchell et al. [14], the efficacy of surgery plus WBRT (Whole-Brain Radiation Therapy) versus radiotherapy alone was investigated. Only single brain metastases were included. The results of the study indicate that patients with a single brain metastasis who receive treatment with surgical resection plus radiotherapy live longer, have fewer recurrences and a better quality of life than those who have been treated only by radiotherapy. In 1992 Smalley et al. [15] evaluated 229 cancer patients with solitary cerebral lesions. All patients underwent craniotomy and part of them adjuvant WBRT. Prognostic factors for the survival time were the extent of systemic disease and gross total removal of cerebral lesions. Patients without systemic disease and total extirpation of brain metastasis had a median survival time of 1.3 years. Patients with systemic disease and subtotal tumor removal had a median survival of 5.3 months only. Adjuvant radiotherapy was associated with improved survival time. Delarive and de Tribolet [16] reported on 81 patients with brain metastases of different origin. All patients were treated by surgery and most of them received postoperative WBRT. The mean survival was 10.2 months. Ten patients survived more than 18 months, 1 patient more than 4 years. Long-term survivors (up to 10 years), even with brain metastases, are known from the literature [17, 18]. Prognostic factors were solitary brain lesions, no extracerebral tumor burden, control of the primary tumor, high Karnofsky performance score and total surgical resection of the cerebral lesion, in most cases accompanied by adjuvant radiotherapy.

In 100 patients with colorectal cancer and brain metastases, the course of disease was studied with respect to single treatment strategies [5]. The different regimens included: surgery, radiotherapy alone, and steroids only. Most patients suffered from additional liver or lung metastases. The mean survival time for patients treated with steroids was 1 month, with radiotherapy alone 3 months, and with surgery alone 9 months. The authors found that the extent of extracerebral metastases did not necessarily lower life expectancy. However, a short interval between the development of the primary tumor and the ap- 
pearance of cerebral metastases worsened the prognosis significantly.

Today, there is little doubt that single brain metastasis should be surgically removed whenever possible $[4,6,19]$. The operative technique of metastasis surgery is routine. Metastatic lesions are usually well circumscribed and show demarcation from the surrounding brain tissue. Small lesions can be approached by neuronavigation. Areas of functional importance can be preserved.

\section{Microneurosurgical Treatment of Multiple Cerebral Metastases}

Treatment of multiple brain metastases ranges from supportive care to conventional radiotherapy, chemotherapy, radiosurgery, and surgical management [20-23]. There is no doubt that the development of multiple metastases implies a fatal prognosis. Surprisingly, patients with multiple metastases can be unimpaired, without significant neurological symptoms. These patients ask for active help. Conventional radiotherapy plays the most important role in treatment of multiple metastases [24]. However, the technical progress in recent years offers additional surgical and radiosurgical methods in treating these patients. In 1993 Bindal et al. [23] presented a review on 56 patients with multiple brain metastases who underwent surgery. In these patients all brain lesions were resected. The median survival time averaged about 14 months. Nussbaum et al. [25] published a study evaluating 729 patients with respect to histology, multiplicity, surgery, and survival. A total of 384 patients presented with a single and 345 with multiple brain metastases. The shortest time interval between diagnosis of the primary tumor and appearance of brain metastases was observed in non-small-cell lung cancer (NSCLC), being 3 months, and the longest in patients with breast cancer, being 53 months. The median survival for patients with a single metastasis treated by surgery was 11 months, and without surgery 3 months. In this study, surgery did not influence survival in patients with multiple metastases. Wronski et al. [26] reported on 231 patients with NSCLC. Subsequent to surgery, median survival time was 11 months. Patients with single metastases survived longer than those with multiple lesions (11.1 vs. 8 months). The conclusion from these studies and others [27, 28] demonstrates that patients with multiple cerebral lesions have a poor prognosis, but might still profit from surgical intervention. Again prognostic factors, e.g. systemic disease, the extent of extracerebral tumor burden, the amount of resection, the location of the lesions, and the Karnofsky performance scale score, are of great importance for the prognosis of the patient. Nowadays, operations in neurosurgery are routinely performed employing neuronavigation. With this method one can resect brain metastases at different sites after optimal planning of the approaches. Small targeted craniotomies are performed for the excision of brain lesions. During the last few years, in our department patients with multiple cerebral metastases (up to four lesions at different sites) have been operated on in one session (fig. 1a-g). The advantage for the patients was that all cerebral lesions were removed in one operation and the duration of hospitalization was no longer than for patients with

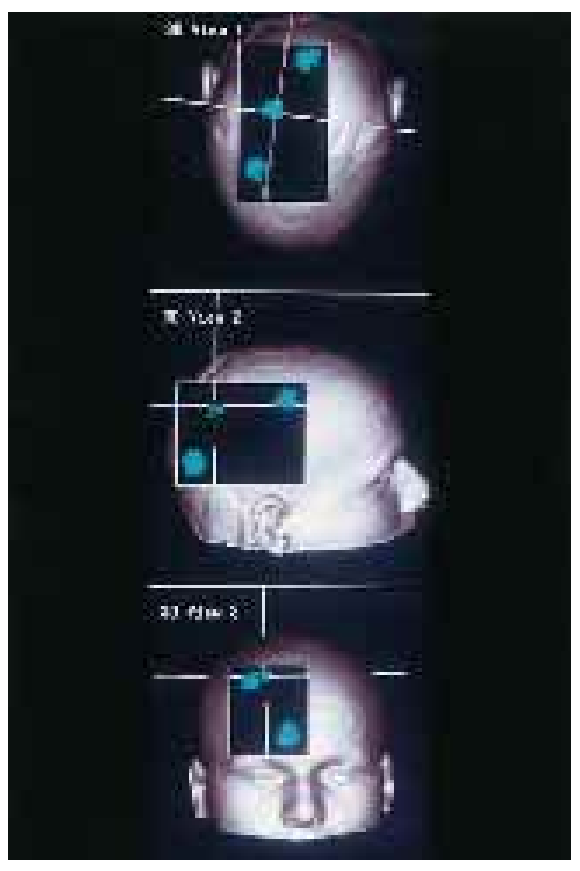

Fig.1. a. Three-dimensional imaging of 3 cerebral metastases by neuronavigation.

single brain metastasis. One important criterion for this management was the preservation of quality of life, which should not be worsened by operative approaches.

\section{Radiotherapy}

Conventional WBRT alone is the most common treatment for patients with brain metastases. Median survival ranges from 3 to 6 months $[24,29,30]$. WBRT has been the mainstay of treatment since the 1950s. The standard treatment regimen is $10 \times 3$ Gy in 2 weeks, appropriate treatment varies depending on radiotherapeutic practices. Trials conducted by the Radiation Therapy Oncology Group (RTOG) indicate that doses ranging from 20 Gy over 1 week to 50 Gy over 4 weeks demonstrate no significant difference in neurological control of disease or length of survival, but that doses $<20$ Gy are less effective [30,31]. Additional focal radiation to the tumor site has no better results than WBRT alone [32]. Large retrospective studies have shown that more than half of these patients treated with WBRT die from extracerebral tumor progression $[2,33]$.

Accelerated and hyperfractionated radiation schedules have been evaluated in several studies of the RTOG. In a randomized phase III study of accelerated hyperfractionation of patients with nonresected brain metastases (1.6 Gy b.i.d. to a total dose of 54.4 Gy vs. an accelerated fractionation of $30 \mathrm{~Gy}$ in 10 daily fractions) no treatment advantage could be found in the accelerated hyperfractionated group. Therefore, results reported from a previously RTOG phase I/II study [34] could not be confirmed [35]

It is still controversial as to whether adjuvant radiotherapy must follow after total extirpation of a solitary cerebral metastasis. Reasons advocating adjuvant radiotherapy are:

1. The incidence of local relapse may be increased in patients without adjuvant radiotherapy. 

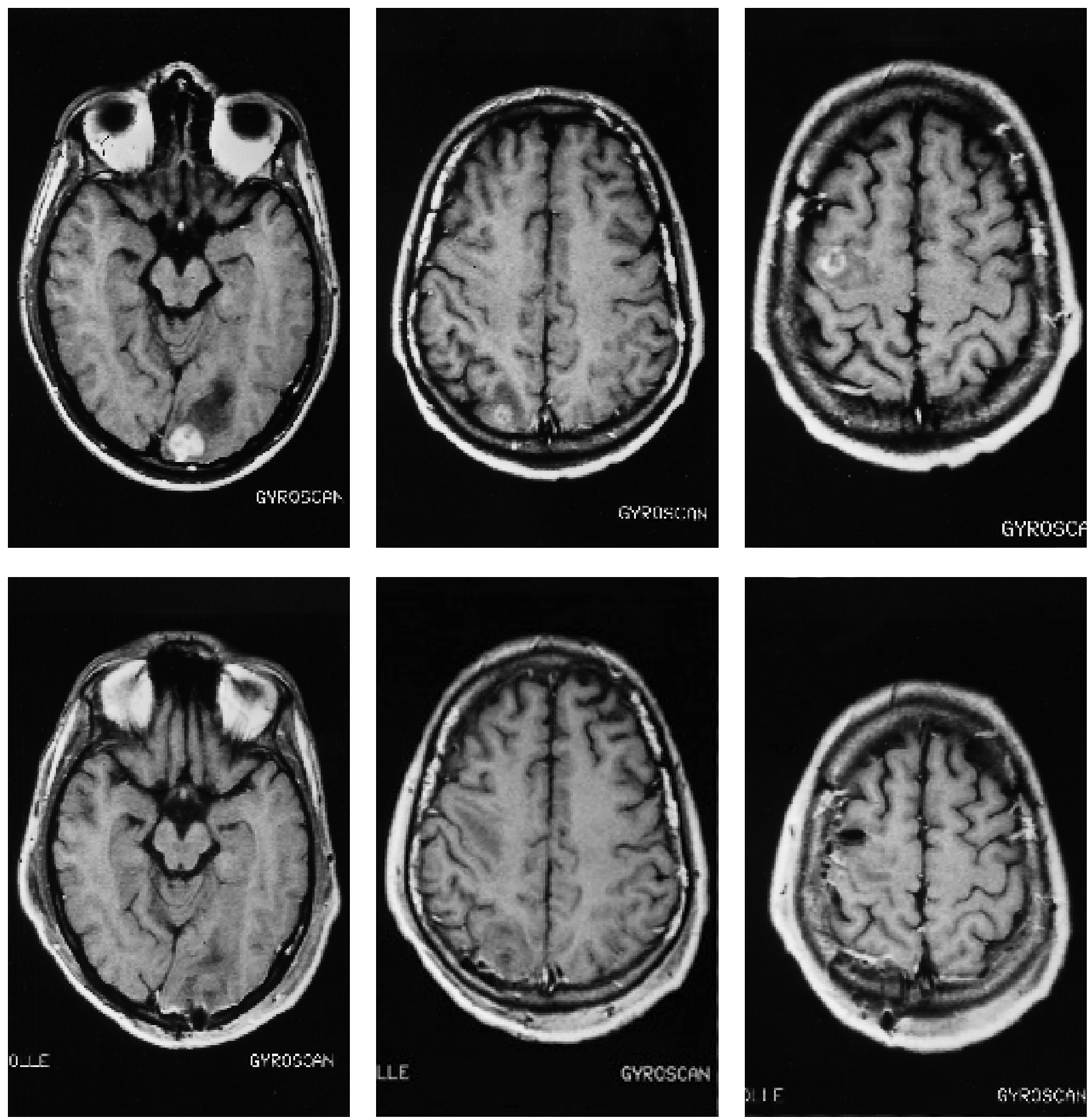

Fig. 1. b-d. MRI T1-weighted volume scan showing 3 brain metastases preoperatively.

Fig. 1. e-g. Postoperative MRI control with contrast media. The patient was treated postoperatively with 30 Gy whole-brain radiotherapy.

2. Small tumor cell clumps not visible by MRI at other sites can be destroyed by WBRT.

Reasons for rejecting radiotherapy are:

1. Brain metastases are usually well defined and can be extirpated completely.

2. Radiotherapy can be preserved for recurrent tumor growth. Several investigators evaluated the efficacy of WBRT in addition to surgery versus WBRT alone [5, 14-16, 36-39]. To date, the overall results of surgical treatment strategies plus adjuvant WBRT indicate that WBRT alone as treatment is inferior to the combined treatment $[5,14]$. Whenever possible, surgical extirpation should be performed. Postoperative radiotherapy, although questionable, may result in a smaller portion of brain relapse and a higher percentage of patients remaining diseasefree [38]. The results of a prospective randomized study to evaluate the efficacy of surgery plus WBRT versus surgery alone are still pending.

In multiple cerebral metastases WBRT alone or in combination with radiosurgery is the favorable treatment $[24,28-31$, 40-42]. In radiosensitive tumors, e. g. small-cell lung cancer [43], 
WBRT alone is the treatment of choice. Age was evaluated as an important factor for the prognosis of patients with cerebral metastasis. Nieder et al. [44] reported on 35 patients older than 70 years of age. The patients received 30 Gy WBRT and were treated with corticosteroids. Six patients received lower or higher total doses with 50.4 Gy at maximum. The median survival time of all patients who completed radiotherapy was 67 days. Patients with extracerebral metastases had a median survival of 31 days. The Karnofsky performance score was the most important prognostic factor. The poor results of this study again reveal the importance of age as prognostic factor.

In some studies, prophylactic cranial irradiation (PCI) has been discussed as prevention for the development of brain metastasis in small-cell lung cancer. The results of these studies [45-48] indicate that the frequency of cerebral seeding is reduced, but not prevented. The brain metastasis-free survival seems to be prolonged.

Long-term ill effects of radiotherapy are usually not a significant issue in the treatment of brain metastases because of the short survival of the patients. Short-term effects are nausea, vomiting, headaches, alopecia, and in some cases fever. In longterm survivors ataxia, urinary incontinence, or even dementia might occur $[49,50]$.

\section{Radiosurgery}

Many publications deal with the results of radiosurgery for single and multiple brain metastases [41, 42, 51-60]. Stereotactic radiosurgery by gamma knife or linear accelerator is judged to be as effective as surgery. The applied doses range between 18 and 20 Gy. In 1987 Sturm et al. [61] described a shrinkage of metastases, reduction of cerebral edema and an improvement in clinical conditions in patients treated radiosurgically by linear accelerator. This was confirmed by others $[42,51]$. The main domain for radiosurgery are small and deep-situated lesions that cannot be approached by surgery. However, the limitation for radiosurgery is size and number of lesions. Alexander et al. [54] reported on 248 patients with 421 lesions treated with a 6-Me V linear accelerator. Patients with a Karnofsky performance score less than 70, evidence of acute neurological deterioration, and tumors larger than $4 \mathrm{~cm}$ in diameter were excluded. The median treatment dose was 1,500 cGy. WBRT was applied in all newly diagnosed patients. The study [54] showed a median survival time of 9.4 months. Prolonged survival was observed in the absence of systemic disease, age younger than 60 years, maximally 2 cerebral lesions, and female sex. Actuarial local control rates were $85 \%$ at 1 year and $65 \%$ at 2 years. Factors associated with a significantly reduced local control rate were location below the tentorium and large tumor volume. The suitability of radiosurgery using the gamma knife was demonstrated by Kida et al. [53]. Cerebral metastases from primary tumors of different origin were treated with doses ranging from 12 to $25 \mathrm{~Gy}$ (mean $18.9 \mathrm{~Gy}$ ). A tumor control rate of 98.2 and $96.6 \%$ was reported after 3 and 6 months, respectively. In a multiinstitutional U.S. study the outcome and prognostic factors subsequent to radiosurgery plus WBRT of single brain metastasis were evaluated [62]. Radiosurgery was performed with a linear accelerator ap- plying a median dose of 17 Gy. In WBRT patients received a median dose of $37.5 \mathrm{~Gy} .122$ patients were treated. The overall local control rate was $86 \%$; the actuarial median survival time after radiosurgery was 56 weeks. The influence of number of lesions on survival was emphasized by Joseph et al. [57]. Survival was equivalent for patients with 1 or 2 lesions to patients with a solitary metastasis treated by surgical resection and WBRT. Survival after radiosurgery for 3 or more lesions was similar to that reported for whole-brain irradiation.

Radiosurgery versus surgery in terms of costs, hospitalization, morbidity, and wider applicability has been discussed by several authors $[60,63]$. Since similar results are reported in radiosurgery and surgery, the cost effectiveness for radiosurgery seems to be more favorable. However, these considerations omit the fact that cerebral lesions should be classified by histology prior to radiotherapeutic treatment. Even if the primary tumor is known, cerebral lesions cannot be classified as metastases by MRI scan without any doubt [64]. Therefore, the patient has to undergo stereotactic biopsy, which mandates hospitalization at least for a short time. Both treatment modalities can be applied in lesions smaller than $3 \mathrm{~cm}$ in diameter, whereas in larger tumors only surgical extirpation is possible.

\section{Treatment of Recurrent Brain Metastases}

The final problem in treating brain metastases is the question of recurrent tumor growth. General opinion supports the decision for active treatment depending on the Karnofsky performance score of the patient, the extent of extracerebral metastases, and the interval of time between the last treatment and the recurrence of the lesions. Bindal et al. [65] evaluated 48 patients who developed recurrent brain metastases. Median survival time from first craniotomy to diagnosis of recurrence was 6.7 months. Median Karnofsky performance score prior to reoperation was 80 . Median survival time after reoperation was 11.5 months. In a multivariate analysis, favorable prognostic factors were defined: no systemic disease, Karnofsky score above 70 , time to recurrence more than 4 months, age above 40 years, primary tumor site with the exception of breast cancer and malignant melanoma. In cases of second recurrence, reoperation was considered. The median survival time averaged about 8.6 months versus 2.4 months for patients who did not undergo a second reoperation. These data were confirmed by Arbit et al. [66] when evaluating 109 patients with recurrent brain metastases of NSCLC. Sawaya et al. [37] stated that whenever possible surgery should remain the treatment of choice, even in recurrent brain metastases.

Wong et al. [67] reported on 86 patients who were reirradiated for progressive brain metastases. All patients had received 30 Gy WBRT previously. The median dose of the second course was $20 \mathrm{~Gy}$. The median survival time averaged about 4 months; in most cases neurological improvement occurred.

The effectiveness of stereotactic radiosurgery for recurrent brain metastases has been investigated in many studies [ $[41,54$, 68, 69]. Breneman et al. [41] treated 79 patients with recurrent tumor growth by radiosurgery. All of these patients had received WBRT before. The applied doses ranged between 16 and $18 \mathrm{~Gy}$. The median survival for the entire group was 
43 weeks from the date of radiosurgery and 71 weeks from the day of original diagnosis of brain metastases. This study and other extirpations $[41,57,68]$ confirmed that patients with up to 2 cerebral metastases, but without active extracerebral tumor burden, showed prolonged survival time due to the applied treatment. In a study protocol of the Radiation Oncology Group, the effectiveness of radiosurgery was investigated with respect to tumor volume and recurrent cerebral metastases. A total of 102 patients were enrolled, of whom 64 had recurrent brain metastases and were irradiated prior with a dose of $30 \mathrm{~Gy}$. Multivariate analysis revealed that a tumor volume of $8,200 \mathrm{~mm}^{3}$ or more is one of the limiting factors in treating patients with recurrent tumors by radiosurgery subsequent to previous irradiation [69].

Taken together, recurrent brain metastases can be approached either by surgery, radiosurgery, or second conventional radiotherapy. Depending on the Karnofsky performance scale, the extent of extracerebral tumor burden, and the time interval between the first cerebral metastasis and the recurrence (which should be more than 5 months), a decision must be made as to whether the patient will be treated surgically or not. Patients in good clinical conditions might profit from surgery. Radiosurgery offers an alternative treatment strategy. Even after previous radiotherapy, radiosurgery can be applied, although the risk for radiation-induced necrosis is increased. The expected median survival time for patients ranges from 6 to 12 months. In addition, a second course of conventional radiotherapy can be considered for some patients, since the routinely used dosage of $30 \mathrm{~Gy}$ allows for a second radiotherapy course.

\section{Chemotherapy}

Chemotherapy has its implication in the treatment of cerebral metastases. The tumor of origin determines the selection of chemotherapeutic agents. However, it has been shown that chemosensitivity from brain metastases can differ from the primary tumor [70]. The prerequisite for adjuvant chemotherapy is the maximal reduction of tumor burden by surgery. Many studies have been published with respect to chemotherapeutic trials of different carcinomas. Combined treatment strategies radiotherapy and chemotherapy - are favored [71-74]. One of the major points in advocating chemotherapy is the simultaneous treatment of cerebral metastases and extracerebral tumor burden. Since cancer is an ongoing disease in which cells constantly separate from tumor lesions and circulate in the bloodstream, the risk for metastatic seeding at different sites is high. Systemic involvement of the disease mandates systemic chemotherapy. The blood-brain barrier (BBB) does not allow the entrance of most of the chemotherapeutic agents into the brain [75]. Whereas lipophilic substances can penetrate the $\mathrm{BBB}$ easily, hydrophilic substances do not. In tumors the BBB is not totally intact. This is called blood-tumor barrier (BTB). The BTB allows the entrance of some additional chemotherapeutic agents, which normally do not gain access to the brain. Furthermore, opening of the BBB with hyperosmotic substances or bradykinine is possible $[76,77]$. The complexity of cancer disease and chemotherapy demands the expertise of specialists.

\section{References}

1 Posner JB: Management of brain metastases. Rev Neurol (Paris) 1992;148:477-487.

2 Cairncross JG, Posner JB: The management of brain metastases; in Walker MD (ed): Oncology of the Nervous System. Boston, MA; Nijhoff, 1983, pp 341-377.

3 Takakura K, Sano K, Hojo S, Hirano, A: Metastatic Tumors of the Central Nervous System. Tokyo, IgakuShoin, 1982.

4 Patchell RA: Brain metastases; in Black P, Loeffler JS (eds): Cancer of the Nervous System, chapt 35. 1997, Boston, Blackwell Science, pp 653-663.

5 Hammoud MA, McCutcheon IE, Elsouki R, Schoppa D, Patt YZ: Colorectal carcinoma and brain metastases: Distribution, treatment, and survival. Ann Surg Oncol 1996:3:453-463.

6 Young B, Patchell RA: Brain metastases; in Youmans JR: Neurological Surgery, ed 4. 1996, Philadelphia, Saunders pp 2748-2760.

7 Sartor K: MR Imaging of the Skull and Brain Heidelberg, Springer, 1992, pp 317-326.

8 Peretti-Viton P, Margain D, Murayama N, Kadr I, Peragut JC: Brain metastases. J Neuroradiol 1991; 18:161-172

9 Golfieri R, Cherryman GR, Olliff JF, Husband JE: Comparative evaluation of computerized tomography / magnetic resonance $(1.5 \mathrm{~T})$ in the detection of brain metastasis. Radiol Med (Torino) 1991;82: 27-34.
10 Kuhn MJ, Hammer GM, Swenson LC, Youssef HT, Gleason TJ: MRI evaluation of 'solitary' brain metastases with triple-dose gadoteridol comparison with contrast-enhanced CT and conventional-dose gadopentetate dimeglumine MRI studies in the same patients. Comput Med Imaging Graph 1994;18: 391-399.

11 Vogl TJ, Friebe CE, Balzer T, Mack MG, Steiner S, Schedel H, Pegios W, Lanksch W, Banzer D, Felix R Diagnosis with cerebral metastasis with standard dose gadobutrol vs. a high dose protocol. Intraindividual evaluation of a phase II high dose study. Radiologe 1995;35:508-516.

12 Murakami K, Nawano S, Moriyama N, Sekiguchi R, Satake M, Fujimoto H, Ichikawa T: Intracranial metastases of hepatocellular carcinoma: CT and MRI. Neuroradiology 1996;38(suppl 1):31-35.

13 van de Pol M, van Oosterhout AG, Wilmik JT, tenVelde GP, Twijnstra A: MRI in detection of brain metastases at initial staging of small-cell lung cancer. Neuroradiology 1996;38:207-210.

14 Patchell RA, Tibbs PA, Walsh JW, Dempsey RJ, Maruyama Y, Kryscio RJ, Markesbery WR Macdonald JS, Young B: A randomized trial of surgery in the treatment of single metastases to the brain. N Engl J Med 1990;322:494-500.

15 Smalley SR, Laws ER Jr, O'Fallon JR, Shaw EG, Schray MF: Resection of solitary brain metastasis. J Neurosurg 1992;77:531-540.
16 Delarive J, de Tribolet N: Cerebral metastases. A study of a surgical series of 81 cases. Neurochirurgie 1992;38:89-97.

17 Famell GF, Buckner JC, Cascino TL, O'Connell MJ, Schomberg PJ, Suman V: Brain metastases from colorectal carcinoma. The long term survivor. Cancer 1996;78:711-716.

18 Nieder C, Walter K, Nestle U, Schnabel K: Ten years disease-free survival after solitary brain metastasis from breast cancer. J Cancer Res Clin Oncol 1996; 122:570-572.

19 Sawaya R, Ligon BL, Bindal RK: Management of metastatic brain tumors. Ann Surg Oncol 1994;1: 169-178.

20 Galicich J, Arbit E: Metastatic brain tumors; in Youmans J (ed): Neurological Surgery, ed 3. Philadelphia, PA, Saunders, 1990, pp 3204-3222.

21 Patchell RA: Brain metastases. Neurol Clin 1991;9: 817-824.

22 Shu HKG, Sneed PK, Shiau CY, McDermott MW, Lamborn KR, Park E, Ho M, Petti PL, Smith V, Verhey LJ, Wara WM, Gutin PH, Larson DA: Factors influencing survival after gamma knife radiosurgery for patients with single and multiple brain metastases. Cancer J Sci Am 1996;2:335.

23 Bindal RK, Sawaya R, Leavens ME, Lee JJ: Surgical treatment of multiple brain metastases. J Neurosurg 1993;79:210-216.

24 Vermeulen SS: Whole brain radiotherapy in the treatment of metastatic brain tumors. Semin Surg Oncol 1998;14:64-69. 
25 Nussbaum ES, Djalilian HR, Cho KH, Hall WA: Brain metastases. Histology, multiplicity, surgery, and survival. Cancer 1996;78:1781-1788.

26 Wronski M, Arbit E, Burt M, Galicich JH: Survival after surgical treatment of brain metastases from lung cancer: A follow-up study of 231 patients treated between 1976 and 1991. J Neurosurg 1995; 83:605-616.

27 Weber F, Riedel A, Koning W, Menzel J: The role of adjuvant radiation and multiple resection within the surgical management of brain metastases. Neurosurg Rev 1996;19:23-32.

28 Wronski M, Arbit E, Russo P, Galicich JH: Surgical resection of brain metastases from renal cell carcinoma in 50 patients. Urology 1996;47:187-193.

29 Sneed PK, Larson DA, Wara WM: Radiotherapy for cerebral metastases. Neurosurg Clin N Am 1996;7 505-515.

30 Borgelt B, Gelber R, Kramer S, Brady LW, Chang $\mathrm{CH}$, Davis LW, Perez CA, Hendrickson FR: The palliation of brain metastases: Final results of the first two studies by the Radiation Therapy Oncology Group. Int J Radiat Oncol Biol Phys 1980;6:1-9.

31 Gelber RD, Larson M, Borgelt BB, Kramer S Equivalence of radiation schedules for the palliative treatment of brain metastases in patients with favorable prognosis. Cancer 1981;48:1749-1753.

32 Hoskins PJ, Crow J, Ford HT: The influence of extent and local management on the outcome of radiotherapy for brain metastases. Int $\mathrm{J}$ Radiat Oncol Biol Phys 1990;19:111-115.

33 Zimm S, Wampler GL, Stablein D, Hazra T, Young HF: Intracerebral metastases in solid-tumor patients: Natural history and results of treatment. Cancer 1981;48: 384-394.

34 Epstein BE, Scott CB, Sause WT, Rotman M, Sneed PK, Janjan NA, Davis LW, Selim H, Mohiuddin M, Wasserman TH: Improved survival duration in patients with unresected solitary brain metastasis using accelerated hyperfractionated radiation therapy at total doses of 54.4 gray and greater: Results of Radiation Oncology Group 85-28. Cancer 1993;71: 1362-1367.

35 Murray KJ, Scott C, Greenberg HM, Emami B, Seider M, Vora NL, Olson C, Whitton A, Movsas B, Curran W: A randomized phase III study of accelerated hyperfrationation versus standard in patients with unresected brain metastases: A report of the Radiation Therapy Oncology Group (RTOG) 9104. Int J Radiat Oncol Biol Phys 1997;39:571-574.

36 Andrews RJ, Gluck DS, Konchingeri RH: Surgical resection of brain metastases from lung cancer. Acta Neurochir (Wien) 1996;138:382-389.

37 Sawaya R, Ligon BL, Bindal AK, Bindal RK, Hess KR: Surgical treatment of metastatic brain tumors. J Neurooncol 1996;27:269-277.

38 Skibber JM, Soong SJ, Austin L, Balch CM, Sawaya RE: Cranial irradiation after surgical excision of brain metastases in melanoma patients. Ann Surg Oncol 1996:3:118-123.

39 Mintz AH, Kestle J, Rathbone MP, Gaspar L, Hugenholtz H, Fisher B, Duncan G, Skingley P, Foster G, Levine M: A randomized trial to assess the efficacy of surgery in addition to radiotherapy in patients with single cerebral metastasis. Cancer 1996:78:1470-1476.

40 Gaspar L, Scott C, Rotman M, Asbell S, Phillips T, Wasserman, T, McKenna WG, Byhardt R: Recursive partitioning analysis (RPA) of prognostic factors in three radiation therapy oncology group (RTOG) brain metastases trials. Int J Radiat Oncol Biol Phys 1997;37:745-751.

41 Breneman JC, Warnicke RE, Albright RE, Kukiatinant N, Shaw J, Armin D, Tew J Jr: Stereotactic radiosurgery for the treatment of brain metastases. Results of a single institution series. Cancer 1997;79:551-557.
42 Mehta MP, Rozental JM, Levin AB, Mackie TR, Kubsad SS, Gehring MA, Kinsella TJ: Defining the role of radiosurgery in the management of brain metastases. Int J Radiat Oncol Biol Phys 1992;24: 619-625.

43 Postmus PE, Haaxma-Reiche H, Gregor A, Groen HJ, Lewinski T, Scolard T, Kirkpatrick A, Curran D, Sahmoud T, Giaccone G: Brain-only metastases of small cell lung cancer; efficacy of whole brain radiotherapy. An EORTC phase II study. Radiother Oncol 1998;46:29-32.

44 Nieder C, Niewald M, Schnabel K: The results of the radiotherapy of brain metastases in patients at an advanced age. Strahlenther Onkol 1995;171: 646-648.

45 Kamath SS, McCarley DL, Zlotecki RA: Decreased metastasis and improved survival with early thoracic radiotherapy and prophylactic cranial irradiation in combined-modality treatment of limited-stage smal cell lung cancer. Radiat Oncol Investig 1998;6 226-232.

46 van de Pol M, ten Velde GP, Wilmink JT, Volovics A Twijnstra A: Efficacy and safety of prophylactic cranial irradiation in patients with small cell lung cancer. J Neurooncol 1997:35:153-160.

47 Kiricuta IC, Bohndorf W: Adjuvant whole-brain irradiation in small-cell bronchial carcinoma Strahlenther Onkol 1996;172:553-558.

48 Stiess J, Kiricuta IC, Müllr G, Bohndorf W: Usefulness of prophylactic whole brain irradiation in smal cell bronchial carcinoma. Strahlenther Oncol 1995; 71:284-289.

49 DeAngelis LM, Delattre JY, Posner JB: Radiationinduced dementia in patients cured of brain metastases. Neurology 1989:39:789-796.

50 Paleologos NA, Imperato JP, Vick NA: Brain metastases: Effects of radiotherapy on long-term survivors. Neurology 1991;41(suppl 1):129.

51 Engenhart R, Kimmig BN, Hover KH, Wowra B, Romahn J, Lorenz WJ, van Kaick G, Wannenmacher M: Long-term follow-up for brain metastase treated by percutaneous stereotactic single high dose irradiation. Cancer 1993;71:1353-1361.

52 Kihlström L, Karlsson B, Lindquist C: Gamma knife surgery for cerebral metastases. Implications for survival based on 16 years experience. Stereotact Funct Neurosurg 1993;61(suppl 1):45-50.

53 Kida Y, Kobayashi T, Tanaka T: Radiosurgery of the metastatic brain tumors with gamma knife. Acta Neurochir Suppl (Wien) 1995;63:89-94.

54 Alexander E III, Moriatry TM, Davis RB, Wen PY, Fine HA, Black PM, Kooy HM, Loeffler JS: Stereotactic radiosurgery for the definitive, noninvasive treatment of brain metastases. J Natl Cance Inst 1995;87:34-40.

55 Voges J, Treuer H, Erdmann J, Schlegel W, Pastyr O, Müller RP, Sturm V: Linac Radiosurgery in Brain Metastases. Acta Neurochir 1994;62(suppl):72-76.

56 Seung SK, Shu HK, McDermott MW, Sneed PK, Larson DA: Stereotactic radiosurgery for malignan melanoma to the brain. Surg Clin North Am 1996;76:1399-1411.

57 Joseph J, Adler JR, Cox RS, Hancock SL: Linear accelerator-based stereotaxic radiosurgery for brain metastases: the influence of number of lesions on survival. J Clin Oncol 1996;14:1085-1092.

58 Valentino $\mathrm{V}$ : The results of radiosurgical management of 139 single cerebral metastases. Acta Neurochir Suppl (Wien) 1995;63:95-100.
59 Flickinger JC, Kondziolka D, Lunsford LD, Coffey RJ, Goodman ML, Shaw EG, Hudgins WR, Weiner R, Harsh GR 4th, Sneed PK, Larson DA: A multiinstitutional experience with stereotactic radiosurgery for solitary brain metastasis. Int J Radiat Oncol Biol Phys 1994;28:797-802.

60 Rutigliano MJ, Lunsford LD, Kondziolka D, Strauss MJ, Khanna V, Green M: The cost effectiveness of stereotactic radiosurgery versus surgical resection in the treatment of solitary metastatic brain tumors Neurosurg 1995;37:445-453.

61 Sturm V, Kober B, Höver KH, Schlegel W, Boesecke R, Pastyr O, Hartmann GH, Schabbert S, zum Winkel K, Kunze S, Lorenz WJ: Stereotactic percutaneous single dose irradiation of brain metastases with a linear accelerator. Int J Radiat Oncol Biol Phys 1987;13:279-282.

62 Auchter RM, Lamond JP, Alexander III E, Noyes WR, Schultz CJ, Loeffler JS, Mehta MP: A multiinstitutional outcome and prognosis analysis of radiosurgery for resectable single brain metastasis. Int J Radiat Oncol Biol Phys 1996;35:27-35.

63 Ostertag CB: Stereotaxic radiosurgery. Nervenarzt 1994;65:660-669.

64 Patchell RA, Cirrincione C, Thaler HT, Galicich JH, Kim J-H, Posner JB: Single brain metastases: surgery plus radiation or radiation alone. Neurology 1986;36: 447-453.

65 Bindal RK, Sawaya R, Leavens ME, Hess KR, Taylor SH: Reoperation for recurrent metastatic brain tumors. J Neurosurg 1995;83:600-604.

66 Arbit E, Wronski M, Burt M, Galicich JH:The treatment of patients with recurrent brain metastases. A retrospective analysis of 109 patients with non-small cell lung cancer. Cancer 1995;76:765-773.

67 Wong WW; Schild SE, Sawyer TE, Shaw EG: Analysis of outcome in patients reirradiated for brain metastases. Int J Radiat Oncol Biol Phys 1996;34: $585-590$

68 Alexander E 3rd, Loeffler JS: Recurrent Brain metastases. Neurosurg Clin N Am 1996;7:517-526.

69 Shaw E, Scott C, Souhami L, Dinapoli R, Bahary JP, Kline R, Wharam M, Schultz C, Davey P, Loeffler J, Del-Rowe J, Marks L, Fisher B, Shin K: Radiosurgery for the treatment of previously irradiated recurrent primary brain tumors and brain metastases: Initial report of radiation therapy oncology group protocol. Int J Radiat Oncol Biol Phys 1996; 34:647-654.

70 Greig NH: Chemotherapy of brain metastases: current status. Cancer Treat Rev 1984;11:157-186.

71 Boogerd W, Dalesio O, Bais EM, van der Sande JJ: Response of brain metastases from breast cancer to systemic chemotherapy. Cancer 1992;69:972-980.

72 Twelves CJ, Souhami RL: Should cerebral metastases be treated by chemotherapy alone? Ann Oncol 1991:2:15-17.

73 Brocker EB, Bohndorf W, Kampgen E, Trcka J, Messer P, Tilgen W, Engenhart K, Flentje M: Fotemustine given simultaneously with total brain irradiation in multiple brain metastases of malignant melanoma: Report on a pilot study. Melanoma Res 1996;6:399-401.

74 Furuse K, Kamimori T, Kawahara M, Kodoma N, Ogawara M, Atagi S, Naka N, Akira M, Kubota K: A pilot study of concurrent whole-brain radiotherapy and chemotherapy combined with cisplatin, vindesin and mitomyin in non-small-cell lung cancer brain metastasis. Br J Cancer 1997;75:614-618.

75 Stewart DJ: A critique of the role of the blood-brain barrier in the chemotherapy of human brain tumors J Neurooncol 1994;20:121-139.

76 Kroll RA, Neuwelt EA: Outwitting the blood-brain barrier for therapeutic purposes: Osmotic opening and other means. Neurosurg 1998;42:1083-1099.

77 Bartus RT, Elliott PJ, Dean RL, Hayward NJ, Nagle TL, Huff MR, Snodgrass PA, Blunt DG: Controlled modulation of BBB permeability using the bradykinin agonist, RMP-7. Exp Neurol 1996;142:14-28. 